\title{
Properties of $\mathrm{Ca}^{2+}$ release induced by clofibric acid from the sarcoplasmic reticulum of mouse skeletal muscle fibres
}

\author{
*,1Takaaki Ikemoto \& ${ }^{1}$ Makoto Endo
}

${ }^{1}$ Department of Pharmacology, Saitama Medical School, Moroyama-machi, Saitama 350-0495, Japan

1 To characterize the effect of clofibric acid (Clof) on the $\mathrm{Ca}^{2+}$ release mechanism in the sarcoplasmic reticulum (SR) of skeletal muscle, we analysed the properties of Clof-induced $\mathrm{Ca}^{2+}$ release under various conditions using chemically skinned skeletal muscle fibres of the mouse.

2 Clof $(>0.5 \mathrm{~mm})$ released $\mathrm{Ca}^{2+}$ from the SR under $\mathrm{Ca}^{2+}$-free conditions buffered with $10 \mathrm{~mm}$ EGTA (pCa >8).

3 Co-application of ryanodine and Clof at $\mathrm{pCa}>8$ but not ryanodine alone reduced the $\mathrm{Ca}^{2+}$ uptake capacity of the SR. Thus, $\mathrm{Ca}^{2+}$ release induced by Clof at $\mathrm{pCa}>8$ must be a result of the activation of the ryanodine receptor (RyR).

4 At $\mathrm{pCa}>8$, (i) Clof-induced $\mathrm{Ca}^{2+}$ release was inhibited by adenosine monophosphate (AMP), (ii) the inhibitory effect of $\mathrm{Mg}^{2+}$ on the Clof-induced $\mathrm{Ca}^{2+}$ release was saturated at about $1 \mathrm{mM}$, and (iii) Clof-induced $\mathrm{Ca}^{2+}$ release was not inhibited by procaine $(10 \mathrm{mM})$. These results indicate that Clof may activate the RyR-Ca ${ }^{2+}$ release channels in a manner different from $\mathrm{Ca}^{2+}$-induced $\mathrm{Ca}^{2+}$ release (CICR). 5 In addition to this unique mode of opening, Clof also enhanced the CICR mode of opening of RyR-Ca ${ }^{2+}$ release channels.

6 Apart from CICR, a high concentration of $\mathrm{Ca}^{2+}$ might also enhance the unique mode of opening by $\mathrm{Clof}$.

7 These results suggest that some features of $\mathrm{Ca}^{2+}$ release activated by Clof are similar to those of physiological $\mathrm{Ca}^{2+}$ release (PCR) in living muscle cells and raise the possibility that Clof may be useful in elucidating the mechanism of PCR in skeletal muscle.

British Journal of Pharmacology (2001) 134, 719-728

Keywords: Calcium release; clofibric acid; sarcoplasmic reticulum

Abbreviations: CICR, $\mathrm{Ca}^{2+}$-induced $\mathrm{Ca}^{2+}$ release; Clof, clofibric acid; PCR, physiological $\mathrm{Ca}^{2+}$ release; RyR, ryanodine receptor; SR, sarcoplasmic reticulum

\section{Introduction}

Control of the intracellular $\mathrm{Ca}^{2+}$ concentration is an important mechanism of regulation of function in a wide variety of cells. Ryanodine receptor (RyR)-mediated $\mathrm{Ca}^{2+}$ release is one of the most important mechanisms in the regulation of cytosolic $\mathrm{Ca}^{2+}$ concentrations (Berridge, 1993). $\mathrm{Ca}^{2+}$-induced $\mathrm{Ca}^{2+}$ release (CICR), a release mechanism from the sarcoplasmic reticulum (SR) extensively studied in skinned fibres (Endo, 1977; 1985) and in isolated SR vesicles (Meissner, 1984; Meissner et al., 1986; Smith et al., 1986), has been shown to be a function of the RyR (Imagawa et al., 1987; Lai et al., 1988; Hymel et al., 1988; Smith et al., 1988).

In skeletal muscle fibres, however, there are several lines of evidence indicating that physiological $\mathrm{Ca}^{2+}$ release (PCR) from the SR is not mediated by CICR (Endo, 1985), but is directly controlled by the voltage sensors in the transverse tubule membrane. The voltage sensors transmit the action potential signals to the $\mathrm{Ca}^{2+}$-release channels on the $\mathrm{SR}$ membrane (Schneider \& Chandler, 1973; Ríos \& Pizarro, 1991; Schneider, 1994). It is generally believed that a common $\mathrm{Ca}^{2+}$-release channel is utilized for both PCR and CICR (Lamb \& Stephenson, 1990; Endo, 1992). Indeed, mice with a targeted mutation of the skeletal muscle RyR (RyR1) gene lack excitation-contraction coupling (Takeshima et al., 1994).

*Author for correspondence; E-mail: tikemoto@saitama-med.ac.jp
Thus, RyR1 apparently functions at least in two opening modes, CICR and PCR.

Various activators and inhibitors of CICR have been reported, including well-known agents such as caffeine, adenine nucleotides, and procaine (Endo, 1985), as well as many new ones (Xu et al., 1998), including 4-chloro- $m$-cresol (Zorzato et al., 1993; Herrmann-Frank et al., 1996) and amentoflavone (Suzuki et al., 1999). However, no agents have been reported to activate the RyR1 by a mode other than CICR.

Clofibric acid (Clof) was reported to increase the probability of opening of the SR $\mathrm{Ca}^{2+}$-release channel incorporated into lipid bilayers, with a complex effect on the function of SR (Sukhareva et al., 1994). In the present study, we analysed the effect of Clof on $\mathrm{Ca}^{2+}$ release in skinned skeletal muscle fibres. Our results demonstrate for the first time that Clof is an agent capable of causing $\mathrm{Ca}^{2+}$ release from the SR via the RyR in a mode quite different from that of CICR.

\section{Methods}

Preparation of skinned muscle fibres

Male mice (ICR, 5-9 weeks) were anaesthetized with 50$80 \mathrm{mg} \mathrm{kg}^{-1}$ sodium pentobarbital (i.p.) and killed by 
decapitation. Skinned fibres were prepared from extensor digitorum longus muscle bundles (EDL, width 2-3 mm) that were treated with saponin $\left(50 \mu \mathrm{g} \mathrm{ml}^{-1}\right)$ for $45 \mathrm{~min}$ in a relaxing solution (in $\mathrm{mM}$ : ATP, 4.76; $\mathrm{Mg}$ methanesulfonate $\left[\mathrm{MgMs}_{2}\right]$ 5.54; potassium methanesulfonate [KMs] 108.6; $\mathrm{NaN}_{3}$ 20; piperazine- $N, N^{\prime}$-bis(2-ethanesulfonic acid) [PIPES] 20; and EGTA 1; pH 7.0) to permeabilize the surface membrane (Endo \& Iino, 1980; Kobayashi et al., 1989). After washout of saponin, thin bundles of three or four fibres were carefully dissected in the relaxing solution and were tied with silk filaments at both ends to a stainless steel wire $(100 \mu \mathrm{m}$ in width). The skinned fibres attached to the metal wire were inserted into a microcuvette with an internal diameter of $400 \mu \mathrm{m}$ and a length of $32 \mathrm{~mm}$.

\section{Measurement of $\mathrm{Ca}^{2+}$ release in skinned fibres}

The $\mathrm{Ca}^{2+}$ released from the SR of the skinned fibres was quantified using Fura-2 (Grynkiewicz et al., 1985). Details of the method are described elsewhere (Iino, 1989; Ikemoto et al., 1995; 1996). Briefly, thin bundles fixed in a capillary cuvette were mounted on the stage of a microscope (BHS-RFK, Olympus, Tokyo, Japan) equipped with a fluorometer (CAM-200, Nihon Bunko Kogyo, Tokyo, Japan) for the measurement of the fluorescence intensity of Fura-2 at $510 \mathrm{~nm}$ with alternating 340 and $380 \mathrm{~nm}$ excitations.

The SR of skinned fibres was actively loaded with $\mathrm{Ca}^{2+}$ for $60 \mathrm{~s}$ in a loading solution (pCa 6.7 and $4 \mathrm{mM} \mathrm{MgATP}$ ), and then the external solution was changed to a $\mathrm{Ca}^{2+}$-free $(\mathrm{pCa}$ $>8$ ) or $\mathrm{Ca}^{2+}$ solution buffered with $10 \mathrm{~mm}$ EGTA (pCa 7.04.5 , test procedure) for induction of $\mathrm{Ca}^{2+}$ release in the absence of ATP for 4-270 s. A test solution containing Clof or other modulators was then applied for a certain period of time to cause $\mathrm{Ca}^{2+}$ release. After washout of the test solution, the external solution was replaced with an assay solution containing $50 \mathrm{mM}$ caffeine, $25 \mathrm{mM}$ AMP, and $35 \mu \mathrm{M}$ Fura-2 to induce complete release of the $\mathrm{Ca}^{2+}$ remaining in the SR and to measure its amount (Endo \& Iino, 1988). In this way, the $\mathrm{Ca}^{2+}$ remaining in the SR after treatment with a test solution can be determined from the fluorescence intensity change of Fura-2 (Iino, 1989; Ikemoto et al., 1995; 1996). The time course of the amount of $\mathrm{Ca}^{2+}$ remaining in the SR was adequately described by a single exponential fall with increasing duration of application of a test solution with or without Clof (Ikemoto et al., 1995; 1996). Therefore, the activity of $\mathrm{Ca}^{2+}$ release was expressed in terms of the decay rate constants based on the amount of $\mathrm{Ca}^{2+}$ remaining in the SR (Iino, 1989; Ikemoto et al., 1995; 1996).

For the direct measurement of $\mathrm{Ca}^{2+}$ release in response to Clof or caffeine, as shown in Figure 1, the fluorescence intensity change of $35 \mu \mathrm{M}$ Fura-2 after constant $\mathrm{Ca}^{2+}$ loading was continuously observed in the absence of $\mathrm{Mg}^{2+}$, ATP, and EGTA and in the presence or absence of $\mathrm{Ca}^{2+}$-releasing stimuli (Ikemoto et al., 1995).

For measurement of the $\mathrm{Ca}^{2+}$-uptake capacity of the SR, the $\mathrm{Ca}^{2+}$ content of the SR was also estimated by the magnitude of the response to caffeine in the presence of Fura-2 after a standard loading procedure but without the test procedure mentioned above (Ikemoto et al., 1995). All experiments were carried out at room temperature $\left(21-23^{\circ} \mathrm{C}\right)$. Statistical
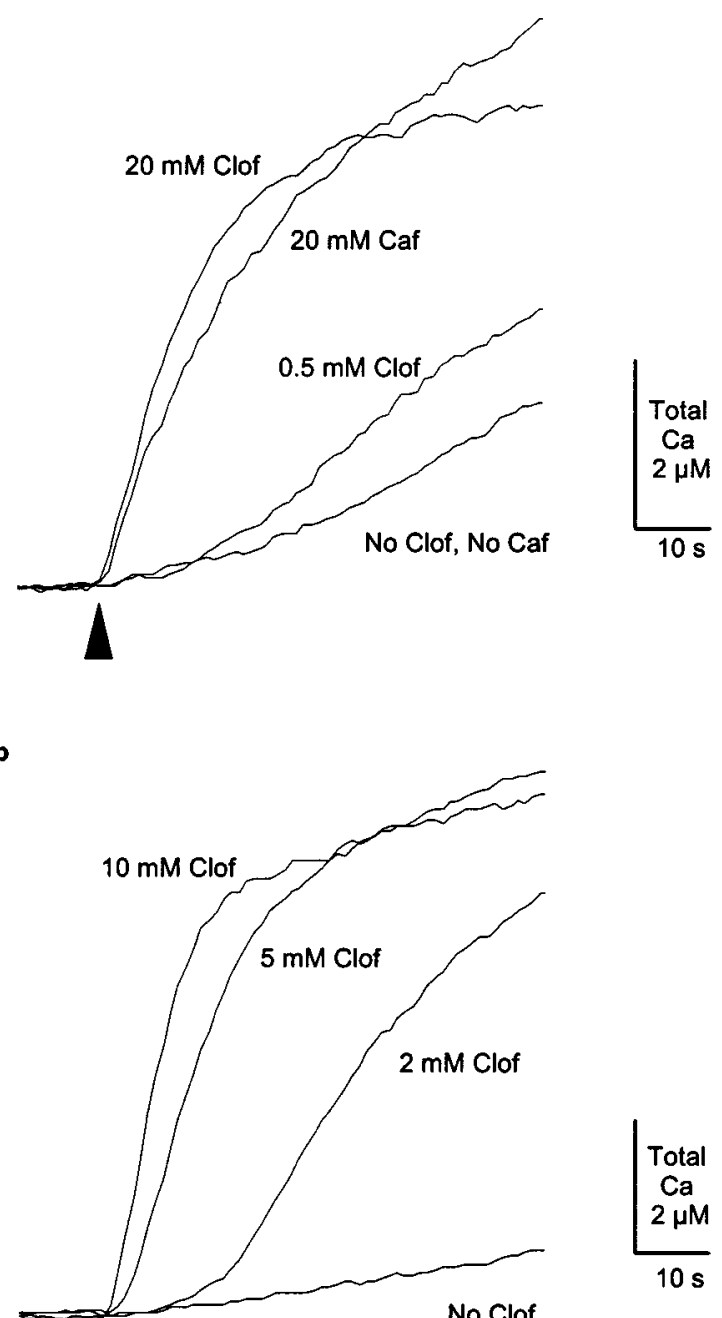

No Clof

Figure 1 Clofibric acid- and caffeine-induced $\mathrm{Ca}^{2+}$ release from the SR. The SR was loaded with $\mathrm{Ca}^{2+}$, and the time course of $\mathrm{Ca}^{2+}$ release was subsequently measured using $35 \mu \mathrm{M}$ Fura- 2 in the absence of $\mathrm{Mg}^{2+}$, ATP, and EGTA. (a) Release of $\mathrm{Ca}^{2+}$ from the SR in the absence and presence of $\mathrm{Ca}^{2+}$-releasing stimuli. Either clofibric acid (Clof, 0.5 and $20 \mathrm{~mm}$ ) or $20 \mathrm{~mm}$ caffeine (Caf) was applied at the time indicated by the arrowhead. (b) Clof $(2-10 \mathrm{~mm})$ was applied at the time indicated by the arrowhead. The data in each panel were obtained from different preparations.

significance was tested by analysis of variance followed by Fisher's protected least significant difference (PLSD) or by the paired $t$-test for comparisons between data with and without drug in the same preparation (Figures 6, 8c, and 9).

\section{Experimental solutions}

The basic composition of all experimental solutions used in this study, including the test solutions and other solutions, was as previously described (Iino, 1989). Solutions of various pCa's $(\leqslant 8)$ were obtained by mixing a $10 \mathrm{~mm}$ EGTAcontaining and a $10 \mathrm{~mm}$ CaEGTA-containing solution. The $\mathrm{pH}$ of these solutions was adjusted to 7.0 with $\mathrm{KOH}$. Clof was dissolved directly in these solutions up to $40 \mathrm{~mm}$ by 
neutralizing with $\mathrm{KOH}$. Thus, the concentration of $\mathrm{K}^{+}$in Clof-containing solutions was higher than those without Clof, and their ionic strength was higher. In order to exclude the possibilities that rather high concentrations of Clof might appreciably bind divalent cations and that a higher ionic strength or $\mathrm{K}^{+}$concentration in the Clof-containing solutions might affect the divalent ion concentrations, the free $\mathrm{Mg}^{2+}$ and the free $\mathrm{Ca}^{2+}$ concentrations in the presence of Clof were measured by the fluorescence change of Mag-Fura-2 (Raju et al., 1989) and of Fura-2, respectively. The presence of $10 \mathrm{~mm}$ Clof did not alter the free $\mathrm{Ca}^{2+}$ concentration, except for a possible small change at $\mathrm{pCa} 5$. Nor did the presence of up to $20 \mathrm{~mm}$ Clof appreciably alter the free $\mathrm{Mg}^{2+}$ concentration. Since the possibilities mentioned above are thus excluded, the effects of addition of Clof may be regarded as the genuine effect of the agent.

\section{Materials}

$\mathrm{Na}_{2} \mathrm{ATP}$ was obtained from Boehringer Mannheim (FRG), saponin from ICN Pharmaceuticals Inc. (U.S.A.), Fura-2 and Mag-Fura-2 from Molecular Probes, Inc. (U.S.A.), and EGTA from Dojindo Laboratories (Japan). AMP, $p$ aminobenzoic acid diethylaminoethyl ester (procaine, Proc) hydrochloride, and 2-(p-chlorophenoxy)-2-methylpropionic acid (clofibric acid, Clof) were purchased from Sigma Chemical Co. (U.S.A.). All other chemicals were of the highest reagent grade available.

\section{Results}

\section{Effect of clofibric acid on $\mathrm{Ca}^{2+}$ release}

After $\mathrm{Ca}^{2+}$ loading of the SR, Clof (0.5-20 mM) induced $\mathrm{Ca}^{2+}$ release from the $\mathrm{SR}$ in the absence of $\mathrm{Mg}^{2+}$, ATP, and EGTA. The rate of release at $20 \mathrm{mM}$ was comparable to that of caffeine at the same concentration (Caf, $20 \mathrm{mM}$ ), (Figure 1). Without caffeine or Clof, $\mathrm{Ca}^{2+}$ was only slowly released from the SR (Figure 1a,b). After $\mathrm{Ca}^{2+}$ release by Clof $(>10 \mathrm{mM})$ for $90 \mathrm{~s}$, $50 \mathrm{~mm}$ caffeine did not induce further $\mathrm{Ca}^{2+}$ release (data not shown). These results indicate that, under these conditions, Clof is able to induce $\mathrm{Ca}^{2+}$ release from the same $\mathrm{Ca}^{2+}$ store in the SR that is influenced by caffeine.

Direct monitoring of the $\mathrm{Ca}^{2+}$ concentration outside the $\mathrm{SR}$, as shown in Figure 1, is not suitable for the quantitative measurement of the $\mathrm{Ca}^{2+}$ release rate, because the CICR channels would be further activated at the later times by the released $\mathrm{Ca}^{2+}$ under such weakly buffered conditions (Endo $\&$ Iino, 1988). We therefore examined the effect of Clof $(10 \mathrm{mM})$ on the rate of $\mathrm{Ca}^{2+}$ release using the protocol described in Methods. Figure 2 shows the time course of $\mathrm{Ca}^{2+}$ release at $\mathrm{pCa}>8(10 \mathrm{~mm}$ EGTA and no added $\left.\mathrm{Ca}^{2+}\right)$. The amount of $\mathrm{Ca}^{2+}$ in the $\mathrm{SR}$ decreased by about $30 \%$ in $120 \mathrm{~s}$ due to leakage of $\mathrm{Ca}^{2+}$ from the SR (Figure $2 \mathrm{a}$, open circles). On the other hand, $10 \mathrm{~mm}$ Clof strongly potentiated the release of $\mathrm{Ca}^{2+}$ from the SR (Figure 2a, filled circles). The $\mathrm{Ca}^{2+}$ release rate was significantly and dose-dependently increased by Clof (Figure 2b). $\mathrm{Mg}^{2+}$ at $0.5 \mathrm{mM}$ significantly suppressed Clof-induced $\mathrm{Ca}^{2+}$ release at all Clof concentrations as well as in the absence of Clof (Figure 2b). a

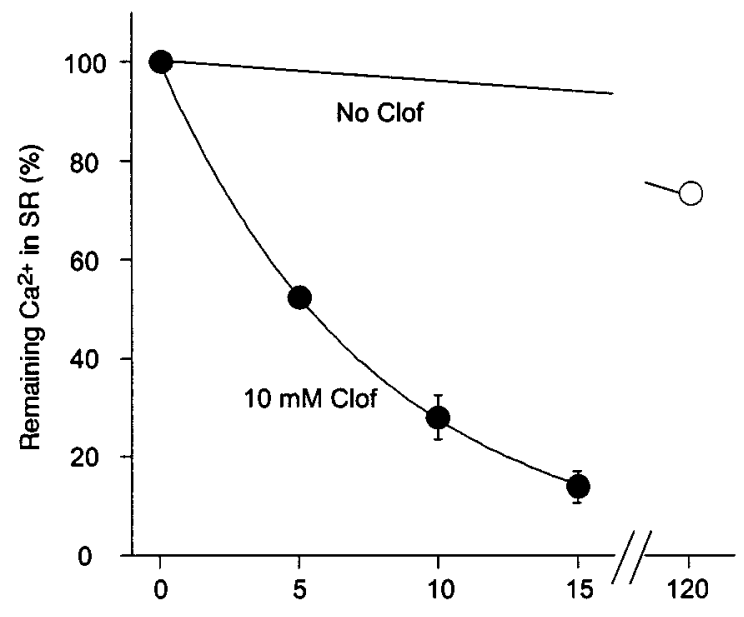

Time (s)

b

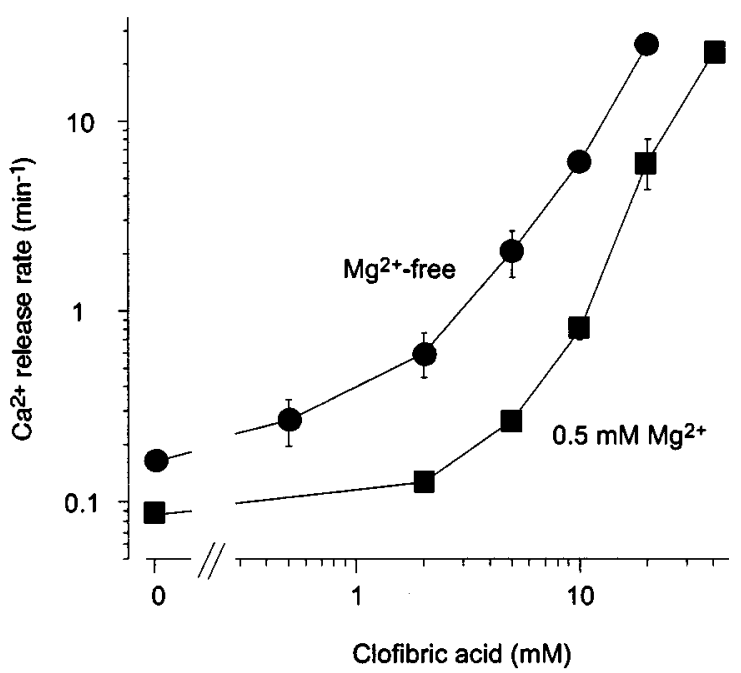

Figure $2 \mathrm{Ca}^{2+}$-releasing effect of Clof in the absence of $\mathrm{Ca}^{2+}$ and its inhibition by $\mathrm{Mg}^{2+}$. (a) With a fixed amount of $\mathrm{Ca}^{2+}$ in the SR at the start, fibres were treated in the absence of $\mathrm{Mg}^{2+}$ with $10 \mathrm{~mm}$ EGTA (no added $\mathrm{Ca}^{2+}$ ) in the presence or absence of $10 \mathrm{~mm}$ Clof for the period of time shown on the abscissa. The $\mathrm{Ca}^{2+}$ remaining in the SR after the treatment was plotted. An exponential curve was fitted by a nonlinear least square method $(n=3)$. (b) The $\mathrm{Ca}^{2+}$ release rates were measured at $\mathrm{pCa}>8$ and plotted against the Clof concentrations applied in the absence or presence of $0.5 \mathrm{~mm} \mathrm{Mg}{ }^{2+}$ (mean \pm s.e.mean, $n=3-9$ ). Error bars smaller than the symbols are not shown.

\section{Reduction of $\mathrm{Ca}^{2+}$-uptake capacity of the SR after co-application of ryanodine and Clof}

A question then arises as to whether the $\mathrm{Ca}^{2+}$ release induced by Clof is through the RyR (CICR) channel or through a different $\mathrm{Ca}^{2}$-release pathway in the $\mathrm{SR}$. We used ryanodine to resolve this question. Ryanodine preferentially binds to activated RyR channels and locks them in an open state. An open-lock of the RyR channels by ryanodine results in the irreversible reduction of the $\mathrm{Ca}^{2+}$-uptake capacity of the SR (Oyamada et al., 1993, Ikemoto et al., 1995). Therefore, if 
Clof activates the RyR, simultaneous application of ryanodine and Clof should cause a reduction of the $\mathrm{Ca}^{2+}$. uptake capacity of the SR.

The effect of ryanodine treatment with or without Clof (10 mM) on the $\mathrm{Ca}^{2+}$-uptake capacity of the $\mathrm{SR}$ was examined (Figure 3). First, the amount of $\mathrm{Ca}^{2+}$ loaded in the SR for $60 \mathrm{~s}$ at pCa 6.7 in the presence of ATP was measured $(100 \%)$. Before the next measurement, ryanodine was applied for $90 \mathrm{~s}$ in the absence of ATP at either $\mathrm{pCa}>8$, 6.5, or 5.5. After washout of ryanodine, the amount of $\mathrm{Ca}^{2+}$ loaded in the SR under the same condition as the first measurement was measured in the same fibres. The $\mathrm{Ca}^{2+}$ uptake capacity in the second measurement changed very little after ryanodine treatment at $\mathrm{pCa}>8.0$, whereas it was significantly reduced at $\mathrm{pCa} 6.5$ and 5.5 (Figure 3, open columns). Without ryanodine, the $\mathrm{Ca}^{2+}$-uptake capacity in the second measurement was not significantly reduced, even at pCa 6.5 or 5.5 (data not shown), as in agreement with a previous report (Ikemoto et al., 1995). Thus, the effect of ryanodine treatment on the $\mathrm{Ca}^{2+}$-uptake capacity was enhanced in a $\mathrm{Ca}^{2+}$-dependent manner. These results suggest that the channel activity under the $\mathrm{Ca}^{2+}$-free condition ( $\mathrm{pCa}$ $>8$ ) was not sufficient for ryanodine to bind to the RyR to a detectable extent within $90 \mathrm{~s}$, while the $\mathrm{Ca}^{2+}$-release channel was activated in a $\mathrm{Ca}^{2+}$-dependent manner. However, after treatment with ryanodine and with $10 \mathrm{mM}$ Clof, even under the $\mathrm{Ca}^{2+}$-free condition, the $\mathrm{Ca}^{2+}$-uptake capacity was significantly reduced (Figure 3, hatched column), indicating that Clof activated the RyR, and it was the cause of the $\mathrm{Ca}^{2+}$ release from the SR in the absence of $\mathrm{Ca}^{2+}$. These results are consistent with the result using the lipid bilayer method in

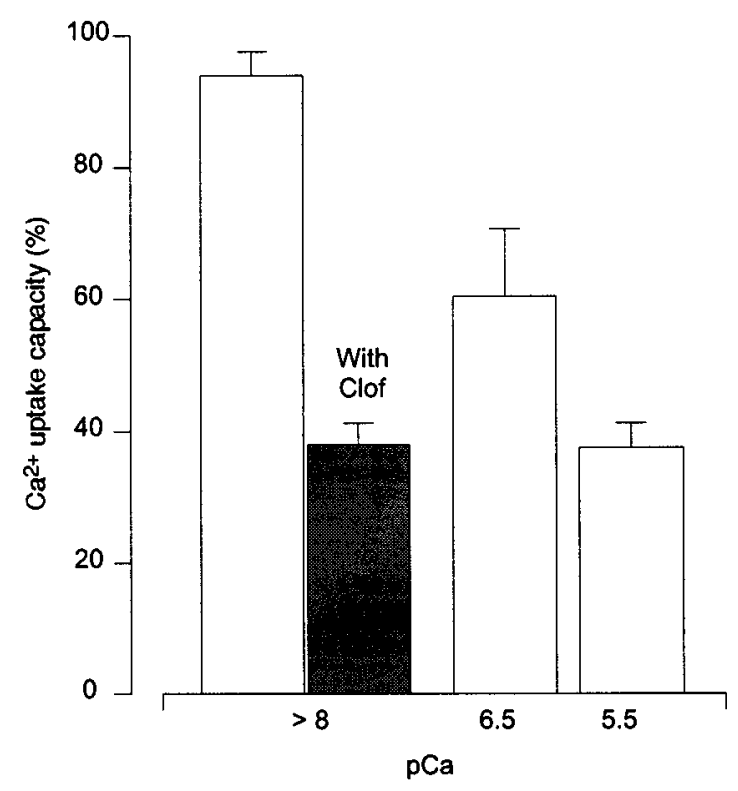

Figure 3 Effect of Clof on the open-lock activity of ryanodine on the SR. The SR was loaded with $\mathrm{Ca}^{2+}$ using the constant procedure, and the amount of $\mathrm{Ca}^{2+}$ released by the subsequent application of $50 \mathrm{~mm}$ caffeine was measured. Two successive measurements were made from the same preparations. The data were normalized by the magnitude of the caffeine response in the first run. Between the runs, muscle fibres were treated with $\mathrm{Ca}^{2+}(\mathrm{pCa}>8,6.5,5.5)$ for $90 \mathrm{~s}$ in the absence of $\mathrm{Mg}^{2+}$ and adenine nucleotide, to which solution either ryanodine $(30 \mu \mathrm{M})$ alone (open column) or both ryanodine and $10 \mathrm{~mm}$ Clof (hatched column) were added (mean \pm s.e.mean, $n=3-4$ ). which Clof increased the open channel probability of the RyR (Sukhareva et al., 1994).

\section{Different effect of modulators of CICR on Clof-induced $\mathrm{Ca}^{2+}$ release}

As shown in the previous sections, Clof can cause intensive $\mathrm{Ca}^{2+}$ release through $\mathrm{RyR}$ channels in the absence of $\mathrm{Ca}^{2+}$. This might suggest that Clof-induced opening of RyR channels is achieved by a mode different from that of CICR. The fact that some modulators of CICR affect Clof-induced $\mathrm{Ca}^{2+}$ release in a quite different manner as described below supports this notion.

Effect of AMP ATP and other adenine compounds are wellknown potentiators of CICR, and this was confirmed in our preparations as well. We used AMP, which strongly increased rates of $\mathrm{Ca}^{2+}$ release induced by $20 \mathrm{mM}$ caffeine in the absence of $\mathrm{Ca}^{2+}$ and $\mathrm{Mg}^{2+}$ (Figure 4, open squares). However, as shown in the same figure, AMP clearly decreased rather than increased the rates of $\mathrm{Ca}^{2+}$ release induced by $20 \mathrm{~mm}$ (open circles) and $10 \mathrm{~mm}$ Clof (filled circles). A similar inhibitory effect was observed with ATP (data not shown).

The rate of $\mathrm{Ca}^{2+}$ release with $20 \mathrm{mM}$ caffeine in the absence of AMP in Figure $4\left(0.9 \mathrm{~min}^{-1}\right)$ is much lower than that reported previously under a similar condition $\left(0.9 \mathrm{~s}^{-1}\right)$ (Rousseau et al., 1988). The reason for the difference is not known at present, but it may well reflect the different preparations used-skinned fibres in the present study and isolated SR vesicles in the previous report.

Effect of $\mathrm{Mg}^{2+}$ It is well known that $\mathrm{Mg}^{2+}$ inhibits CICR As shown in Figure $2 \mathrm{~b}$, Clof-induced $\mathrm{Ca}^{2+}$ release is also

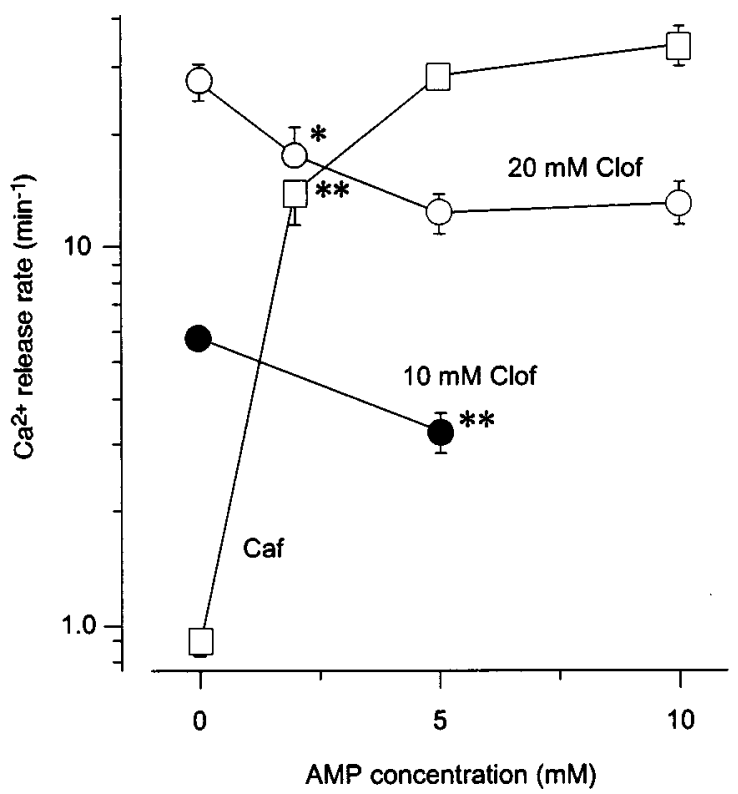

Figure 4 Effect of AMP on Clof- or caffeine-induced $\mathrm{Ca}^{2+}$ release. Dependence on AMP $(0-10 \mathrm{mM})$ of the rate of $\mathrm{Ca}^{2+}$ release was determined with $20 \mathrm{~mm}$ and $10 \mathrm{~mm}$ Clof or caffeine (Caf) at pCa $>8$ under $\mathrm{Mg}^{2+}$-free conditions (mean \pm s.e.mean, $n=4-5$ for $20 \mathrm{~mm}$ Clof, $n=3$ for $10 \mathrm{~mm}$ Clof, $n=3-4$ for Caf). Error bars smaller than the symbols are not shown. ${ }^{*} P<0.05,{ }^{*} P<0.01$ (vs no AMP in each line). 
inhibited by $\mathrm{Mg}^{2+}$. However, we found that the concentration dependence of the inhibitory effect of $\mathrm{Mg}^{2+}$ on Clofinduced $\mathrm{Ca}^{2+}$ release is quite different from that on CICR. The inhibitory effect of $\mathrm{Mg}^{2+}$ on Clof-induced $\mathrm{Ca}^{2+}$ release saturates at about $1 \mathrm{~mm}$, whereas that on caffeine-induced $\mathrm{Ca}^{2+}$ release increases continuously up to $10 \mathrm{~mm}$ (Figure 5, open circles vs open squares). One might argue that the difference in the inhibitory effect of $\mathrm{Mg}^{2+}$ may be related to the difference in $\mathrm{Ca}^{2+}$ concentration between Clof-induced $\mathrm{Ca}^{2+}$ release $\left(\mathrm{pCa}>8\right.$ ) and caffeine-induced $\mathrm{Ca}^{2+}$ release (pCa 6), especially since one of the mechanisms of inhibition by $\mathrm{Mg}^{2+}$ is competition with $\mathrm{Ca}^{2+}$ at the activation site. However, even if caffeine-induced $\mathrm{Ca}^{2+}$ release was examined at $\mathrm{pCa}>8$ (in this case $20 \mathrm{~mm}$ AMP was added to the caffeine-containing medium in place of $\mathrm{Ca}^{2+}$, because in the absence of $\mathrm{Ca}^{2+}$, the rate of caffeine-induced $\mathrm{Ca}^{2+}$ release was too low to examine the effect of inhibitors), $10 \mathrm{mM} \mathrm{Mg}^{2+}$ still exerted a significantly stronger inhibitory effect than $1 \mathrm{mM} \mathrm{Mg}^{2+}$ (data not shown). Considering the fact that there is no appreciable alteration in $\mathrm{Mg}^{2+}$ concentration in Clofcontaining solutions as described in Methods, one must conclude that the difference in $\mathrm{Mg}^{2+}$ concentration dependence described above between Clof-induced and caffeineinduced $\mathrm{Ca}^{2+}$ release is genuine.

Effect of procaine Procaine is a well-known inhibitor of CICR, and we could also demonstrate an inhibitory effect with procaine. Caffeine-induced $\mathrm{Ca}^{2+}$ release was clearly

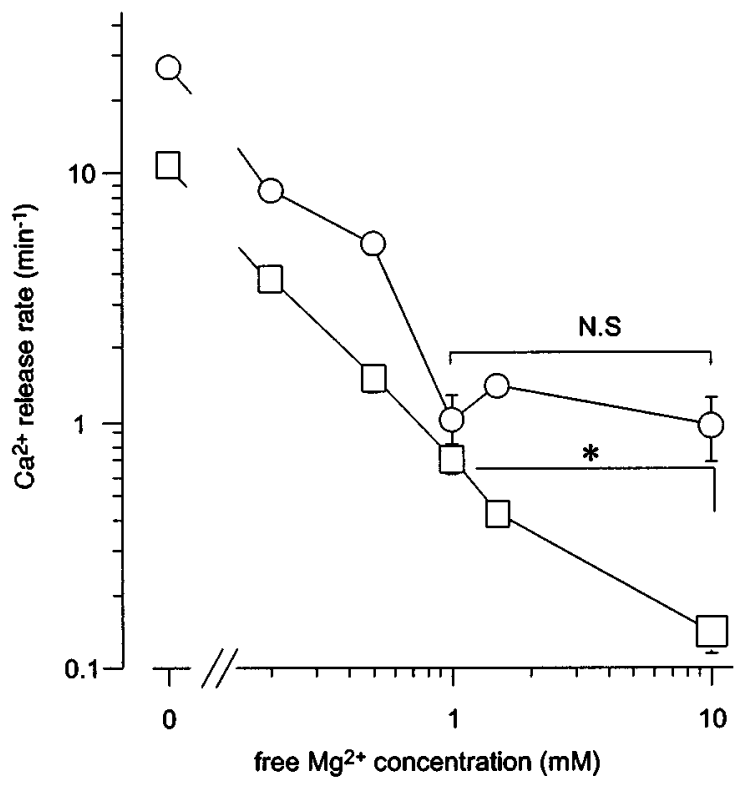

Figure 5 Effect of $\mathrm{Mg}^{2+}$ on Clof- or caffeine-induced $\mathrm{Ca}^{2+}$ release. Dependence on $\mathrm{Mg}^{2+}(0-10 \mathrm{mM})$ of the rate of $\mathrm{Ca}^{2+}$ release was determined with $20 \mathrm{~mm}$ Clof at $\mathrm{pCa}>8$ or with caffeine (Caf) at pCa 6.0 in the absence of AMP. The concentration of total $\mathrm{Mg}$ (added as $\mathrm{MgMs}_{2}$ ) in the $0.2,0.5,1.0,1.5$, and $10 \mathrm{~mm}$ free $\mathrm{Mg}^{2+}$ test solutions at $\mathrm{pCa}>8$ (with Clof) were $0.27,0.67,1.33,1.99$, and $12.55 \mathrm{~mm}$, respectively. The concentration of total $\mathrm{Mg}$ in the $0.2,0.5,1.0,1.5$, and $10 \mathrm{~mm}$ free $\mathrm{Mg}^{2+}$ test solutions at pCa 6.0 (with caffeine) were $0.22,0.55,1.10,1.64$, and $10.88 \mathrm{~mm}$, respectively. Caffeine was used at pCa 6.0 because it could not cause an appreciable $\mathrm{Ca}^{2+}$ release at $\mathrm{pCa}>8.0$ (mean \pm s.e.mean, $n=5$ ). ${ }^{*} P<0.05$. N.S., not significant. Error bars smaller than the symbols are not shown. inhibited by procaine in the absence of $\mathrm{Ca}^{2+}, \mathrm{Mg}^{2+}$, and AMP (Figure 6b). However, Clof-induced $\mathrm{Ca}^{2+}$ release under similar conditions was not inhibited by the same concentration of procaine (Figure 6a).

\section{Effect of Clof on CICR}

The experiments with Clof described thus far were all conducted in the practical absence of $\mathrm{Ca}^{2+}$. We also examined the effect of Clof in the presence of various concentrations of $\mathrm{Ca}^{2+}$, and compared the results with those

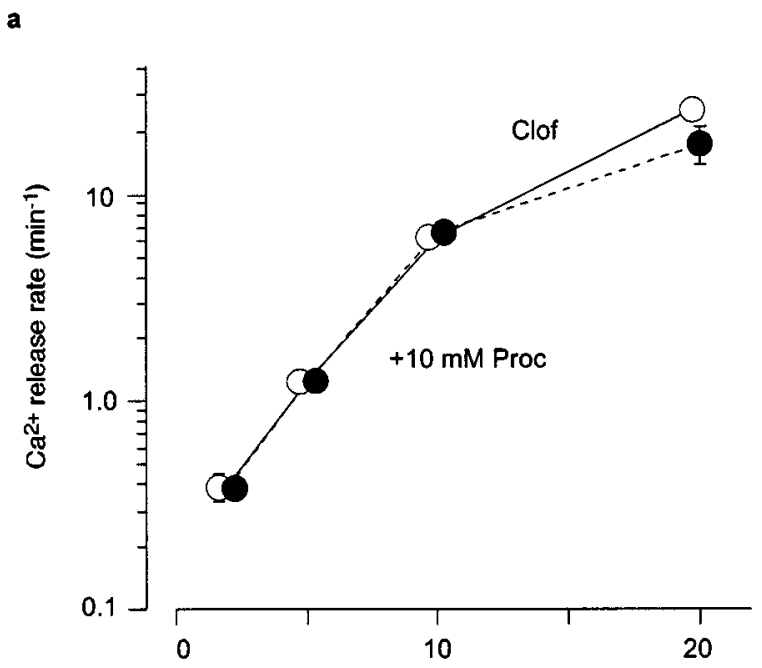

Clof concentration (mM)

b

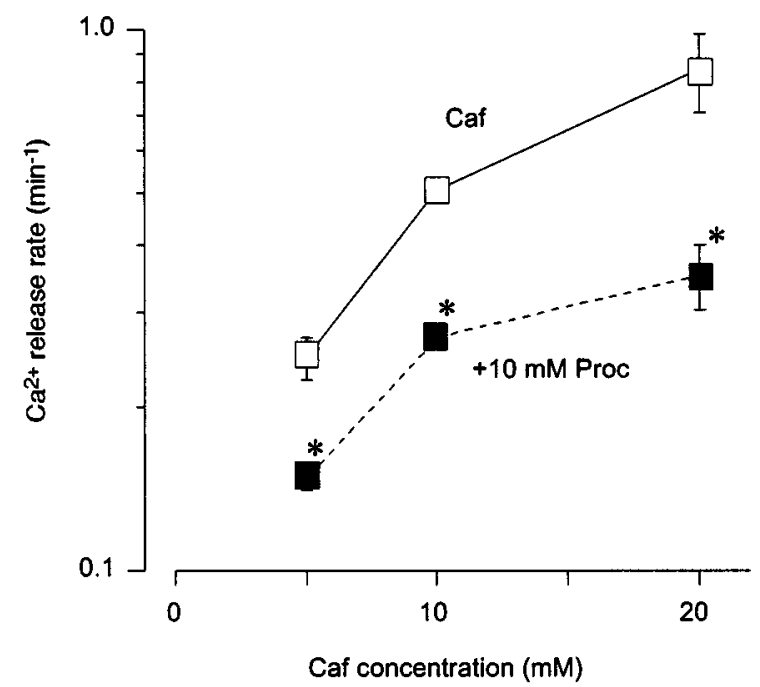

Figure 6 Effect of procaine on Clof- or caffeine-induced $\mathrm{Ca}^{2+}$ release. Under $\mathrm{Mg}^{2+}-$, AMP-, and $\mathrm{Ca}^{2+}$-free conditions ( $\mathrm{pCa}>8$ ), the rate of $\mathrm{Ca}^{2+}$ release with 2-20 mM Clof (a) or 5-20 mM Caf (b) was measured in the presence or absence of $10 \mathrm{~mm}$ procaine (Proc) (mean \pm s.e.mean, $n=3-5$ for Clof, $n=3$ for Caf). The paired data with procaine or without procaine were obtained from the same preparation at each Clof or Caf concentration. $* P<0.05$. Symbols at $2-10 \mathrm{~mm}$ Clof were slightly offset horizontally for clarity. Error bars smaller than the symbols are not shown. Note the difference in the scales. 
of caffeine. Experiments were conducted in the presence of $0.5 \mathrm{mM} \mathrm{Mg}^{2+}$. The presence of Clof $(10 \mathrm{mM})$ potentiated the $\mathrm{Ca}^{2+}$ release at all $\mathrm{Ca}^{2+}$ concentrations tested $(\mathrm{pCa}>8, \mathrm{pCa}$ $7-4.5$, Figure $7 \mathrm{a}$, open triangles vs filled circles). The rate of $\mathrm{Ca}^{2+}$ release by Clof at higher $\mathrm{Ca}^{2+}$ concentrations (7.15 $\mathrm{min}^{-1}$ at $\mathrm{pCa} 5.0$, filled circles) is very much greater than the sum of the $\mathrm{Ca}^{2+}$ release rate by Clof at $\mathrm{pCa}>8$ $\left(0.78 \mathrm{~min}^{-1}\right.$ at $\mathrm{pCa}>8$, filled circles) and that by $\mathrm{Ca}^{2+}$ alone (0.59 $\mathrm{min}^{-1}$ at $\mathrm{pCa} 5.0$, open triangles). This indicates that the model of independent $\mathrm{Ca}^{2+}$-release channels for Clofinduced $\mathrm{Ca}^{2+}$ release and for CICR should be abandoned. These results suggest that Clof potentiates CICR. The presence of caffeine $(10 \mathrm{mM})$ also potentiated the $\mathrm{Ca}^{2+}$ release at low $\mathrm{Ca}^{2+}$ concentrations ( $\mathrm{pCa}$ 6.5), while it exhibited no effect in the absence of $\mathrm{Ca}^{2+}(\mathrm{pCa}>8)$ or at the high $\mathrm{Ca}^{2+}$ concentrations (pCa 5.0 and 4.5, Figure 7a, open circles vs open triangles).

We also carried out similar experiments in the presence of AMP. AMP itself potentiated $\mathrm{Ca}^{2+}$ release only at higher $\mathrm{Ca}^{2+}$ concentrations (Figure 7a, open triangles vs Figure 7b, filled triangles), which is in marked contrast to that of caffeine, which increased the calcium sensitivity of CICR (Figure 7a, open triangles vs open circles; Endo, 1977; 1985). Co-application of caffeine and AMP significantly increased the rate of $\mathrm{Ca}^{2+}$ release at $\mathrm{pCa}<7$ (Figure $8 \mathrm{~b}$, open circles). On the other hand, the rate of $\mathrm{Ca}^{2+}$ release with Clof at low $\mathrm{Ca}^{2+}$ concentrations ( $\mathrm{pCa}>5.5$ ) was significantly reduced in the presence of AMP, while it was increased at the higher $\mathrm{Ca}^{2+}$ concentrations $(\mathrm{pCa}<5.0$, filled circles, Figure $7 \mathrm{a}$ vs b). The inhibitory effect of AMP on Clof-induced $\mathrm{Ca}^{2+}$ release at the low $\mathrm{Ca}^{2+}$ concentrations is consistent with the results shown in Figure 4. The potentiating effect of AMP on Clof- induced $\mathrm{Ca}^{2+}$ release at the high $\mathrm{Ca}^{2+}$ concentrations supports the notion proposed in the previous paragraph that Clof also potentiates CICR. Indeed, unlike at low $\mathrm{Ca}^{2+}$ concentrations, modulators of CICR now exert their usual effects on Clof-induced $\mathrm{Ca}^{2+}$ release at high $\mathrm{Ca}^{2+}$ concentrations. Thus, AMP dose-dependently enhanced Clof-induced $\mathrm{Ca}^{2+}$ release (Figure 8a), in accordance with the result of Figure 7. The inhibition by $\mathrm{Mg}^{2+}$ is not saturated at $1 \mathrm{~mm}$, as much stronger inhibition was obtained at $10 \mathrm{~mm}$ (Figure $8 b$ ). Furthermore, $10 \mathrm{~mm}$ procaine now clearly inhibits Clofinduced $\mathrm{Ca}^{2+}$ release (Figure $8 \mathrm{c}$ ).

\section{Effect of high concentrations of $\mathrm{Ca}^{2+}$ on Clof-induced $\mathrm{Ca}^{2+}$ release independent of $C I C R$}

Finally, we examined the effect of various concentrations of $\mathrm{Ca}^{2+}$ on Clof-induced $\mathrm{Ca}^{2+}$ release under maximum inhibition of CICR. For this purpose, we used $10 \mathrm{~mm}$ $\mathrm{Mg}^{2+}$ together with $10 \mathrm{mM}$ procaine (Figure 9). Under this condition, quite contrary to the results at low $\mathrm{Mg}^{2+}$ concentrations (open triangles in Figure 7a), the rates of $\mathrm{Ca}^{2+}$ release without Clof were decreased at $\mathrm{pCa}<6$ (Figure 9, open squares). The results with $10 \mathrm{mM} \mathrm{Mg}^{2+}$ alone were much the same (data not shown). Thus, CICR activity was strongly inhibited in the presence of $10 \mathrm{~mm}$ $\mathrm{Mg}^{2+}$. However, Clof still caused a greater increase in the rate of $\mathrm{Ca}^{2+}$ release at $\mathrm{pCa} 5.0$ than at high pCas (Figure 9, filled squares). These results suggest that a high concentration of $\mathrm{Ca}^{2+}$ might also enhance Clof-induced $\mathrm{Ca}^{2+}$ release independent of CICR, although it is difficult to exclude completely the possibility that some CICR activity still remained under this condition.
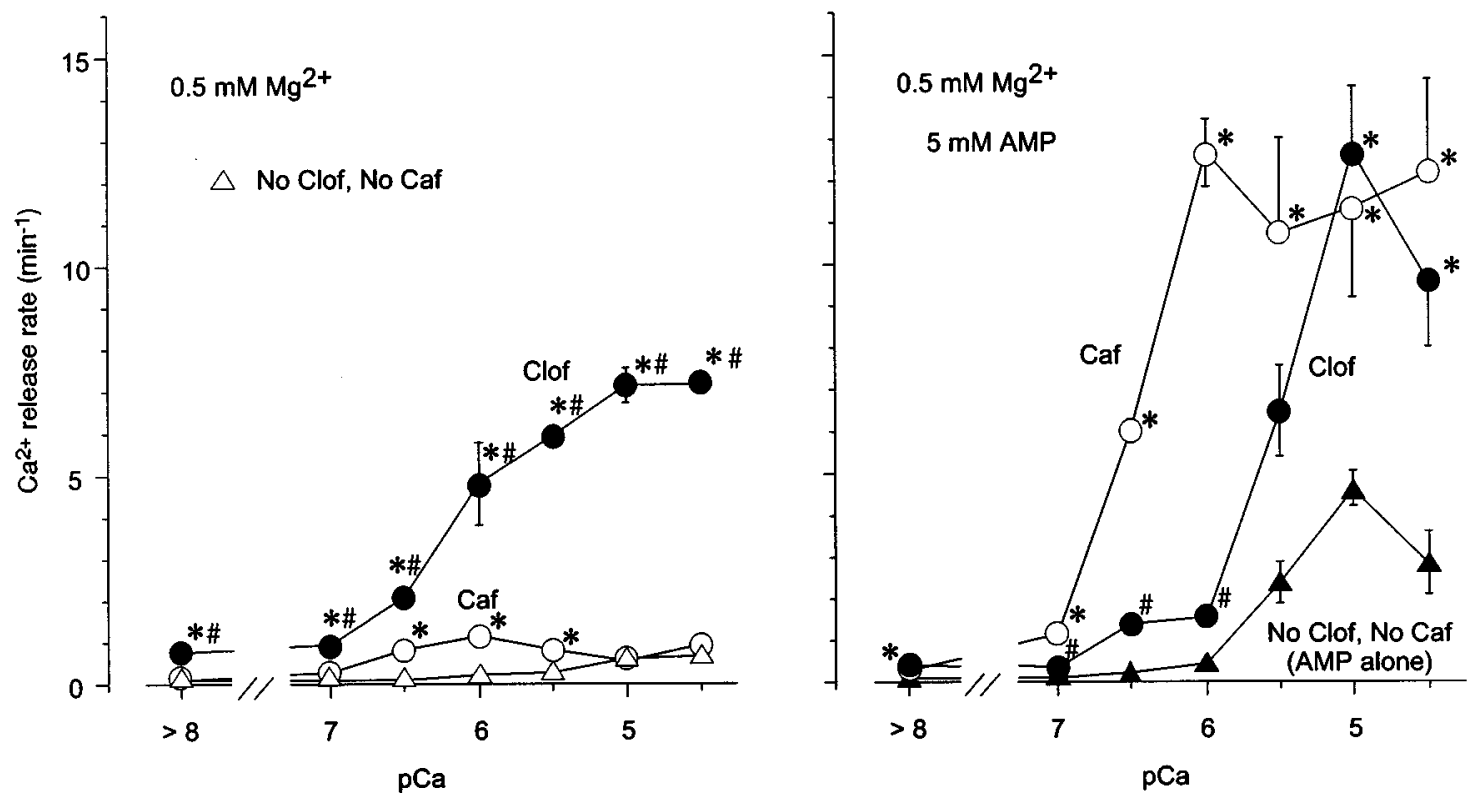

Figure 7 Effect of Clof on the rates of $\mathrm{Ca}^{2+}$ release under various $\mathrm{Ca}^{2+}$ concentrations. In the presence of $0.5 \mathrm{mM} \mathrm{Mg}^{2+}$, the rate of $\mathrm{Ca}^{2+}$ release was measured at a range of $\mathrm{pCa}>8-4.5$ with $10 \mathrm{~mm}$ Clof, $10 \mathrm{~mm}$ Caf, or without both agents (CICR activity without any agents), in the absence (a) or presence of $5 \mathrm{mM}$ AMP (b). The data with AMP alone are shown in $b$ (mean \pm s.e.mean, $n=3-9$ for each panel). ${ }^{*} P<0.05$ (vs control or AMP alone), $\# P<0.05$ (vs Caf). Error bars smaller than the symbols are not shown. 
a

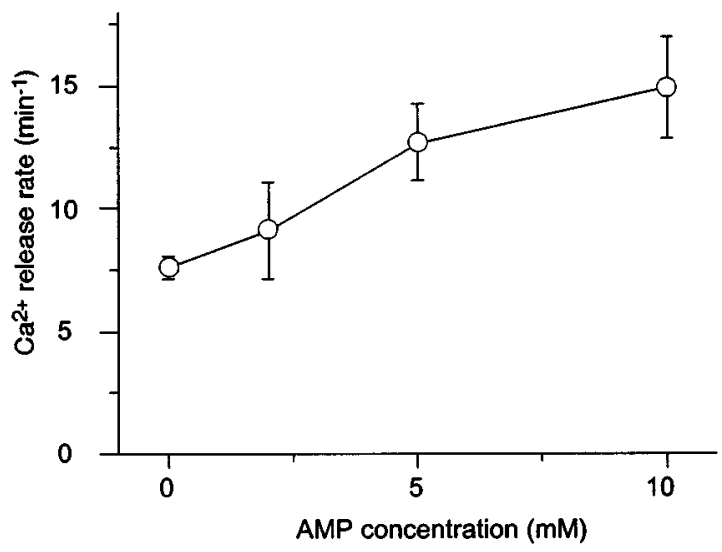

b

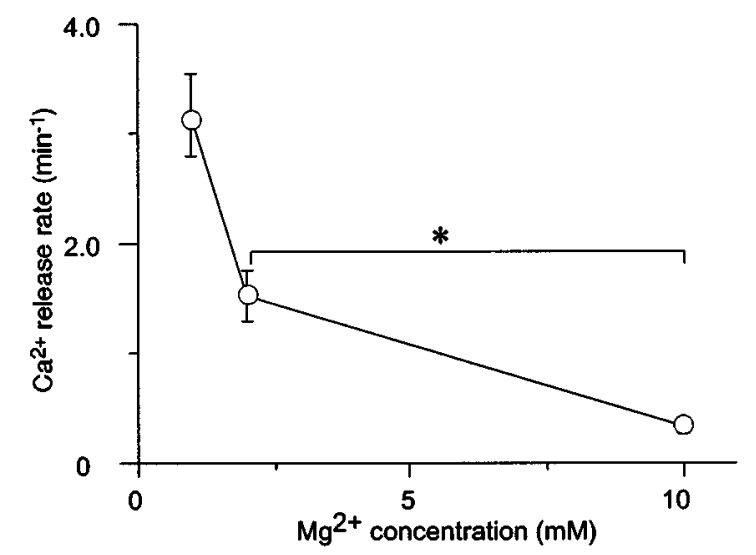

c

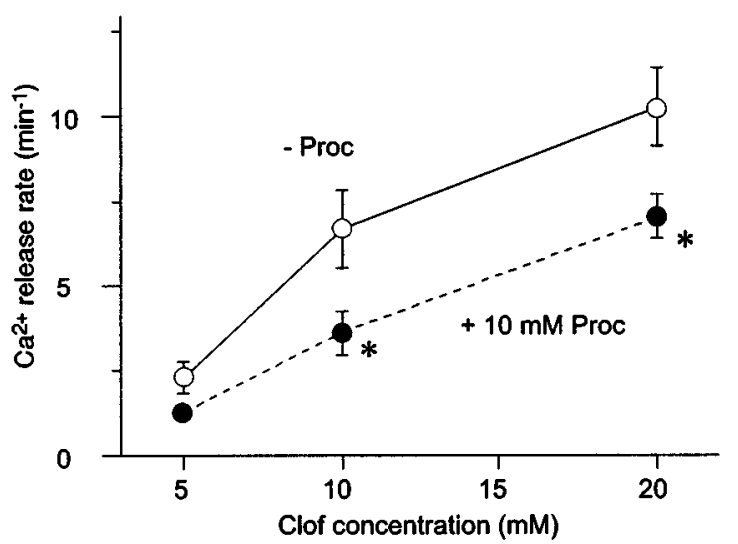

Figure 8 Effects of modulators of CICR on Clof-induced $\mathrm{Ca}^{2+}$ release at a high $\mathrm{Ca}^{2+}$ concentration. The rates of $\mathrm{Ca}^{2+}$ release with Clof (20 $\mathrm{mm}$ in a and b, 5-20 mM in c) were measured in the presence of AMP $(0-10 \mathrm{mM}, \mathrm{a}, n=3), \mathrm{Mg}^{2+}(1-10 \mathrm{mM}, \mathrm{b}, n=3)$, or $10 \mathrm{mM}$ procaine (Proc, c, $n=4$ ) at pCa 5.0. The data in a and $\mathrm{c}$ were obtained at $0.5 \mathrm{~mm} \mathrm{Mg}^{2+}$. The experiments in $\mathrm{b}$ and $\mathrm{c}$ were carried out under AMP-free conditions (mean \pm s.e.mean). In $\mathrm{c}$, the paired data with procaine or without procaine were obtained from the same preparation at each Clof concentration. ${ }^{*} P<0.05$. Note the difference in the scales.

\section{Discussion}

Unique mode of opening of RyR by Clof

In this study, we described the unique effects of Clof on the $\mathrm{Ca}^{2+}$ release in saponin-skinned skeletal muscle fibres. There

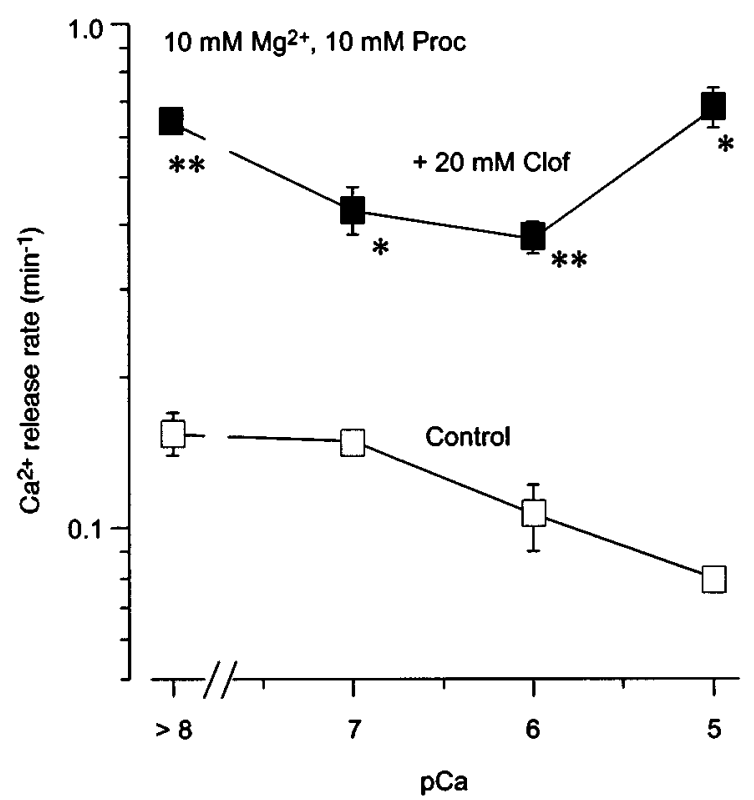

Figure 9 Enhancing effect of Clof on $\mathrm{Ca}^{2+}$ release in the presence of a high concentration of $\mathrm{Mg}^{2+}$ and procaine. The rates of $\mathrm{Ca}^{2+}$ release with or without $20 \mathrm{~mm}$ Clof were measured in the presence of $10 \mathrm{mM} \mathrm{Mg}^{2+}$ and $10 \mathrm{~mm}$ procaine (Proc) (mean \pm s.e.mean, $n=3$ ). The paired data with or without Clof were obtained from the same preparation at each $\mathrm{Ca}^{2+}$ concentration. $* P<0.05$, $* * P<0.01$.

were several major differences between CICR and Clofinduced $\mathrm{Ca}^{2+}$ release. First, Clof strongly increased the rate of $\mathrm{Ca}^{2+}$ release in the absence of $\mathrm{Ca}^{2+}$. Second, AMP, an adenine nucleotide, inhibited the Clof-induced $\mathrm{Ca}^{2+}$ release, quite contrary to its effect on CICR. Third, the inhibitory effect of $\mathrm{Mg}^{2+}$ was saturated at about $1 \mathrm{mM}$, again contrary to its effect on CICR. Finally, procaine, a CICR inhibitor, failed to inhibit the Clof-induced $\mathrm{Ca}^{2+}$ release. This unique mode of $\mathrm{Ca}^{2+}$ release by Clof is a result of opening of the RyR-Ca ${ }^{2+}$-release channel, because ryanodine applied together with Clof at $\mathrm{pCa}>8$ could lock the $\mathrm{Ca}^{2+}$-release channel in an open state, thereby bringing about the reduction of the $\mathrm{Ca}^{2+}$-uptake capacity of the SR (Figure 3).

\section{Activation of CICR by Clof}

Apart from the unique mode of opening, the $\mathrm{Ca}^{2+}$-dependent increase of the rate of Clof-induced $\mathrm{Ca}^{2+}$ release (Figure 7a) suggested that Clof also has an enhancing effect on CICR, and this was supported by the facts that, unlike in the absence of $\mathrm{Ca}^{2+}$, at higher $\mathrm{Ca}^{2+}$ concentrations modulators of CICR exert their usual effects on Clof-induced $\mathrm{Ca}^{2+}$ release: it is enhanced by AMP, more strongly inhibited by $10 \mathrm{mM} \mathrm{Mg}^{2+}$ than by $1 \mathrm{mM}$, and inhibited by procaine (Figure 8). The enhancing effect of Clof on CICR is similar to that of adenine compounds in that, unlike the effect of caffeine, the $\mathrm{Ca}^{2+}$ sensitivity of CICR was not altered, so that the shape of the curve plotted against $\mathrm{Ca}^{2+}$ concentrations in the range of $\mathrm{pCa}<5.5$ is similar with and without Clof (Figure 7).

Thus, Clof exerts enhancing effects on both CICR and some other activating mode of RyR simultaneously. The dual effects of Clof in the presence of $\mathrm{Ca}^{2+}$ can explain the discrepancy that the effects of Clof seem to level off even at 
Table 1 Comparison of Clof-induced $\mathrm{Ca}^{2+}$ release with PCR and CICR

\begin{tabular}{|c|c|c|c|c|c|c|}
\hline $\begin{array}{l}\text { Mode of } \\
\text { opening }\end{array}$ & $\begin{array}{l}\text { Stimulus to cause } \\
\mathrm{Ca}^{2+} \text { release }\end{array}$ & $\begin{array}{l}\mathrm{Ca}^{2+} \\
\text { requirement }\end{array}$ & $\begin{array}{c}\text { Adenine } \\
\text { compounds } \\
\text { potentiation }\end{array}$ & $\begin{array}{l}\text { Ryanodine } \\
\text { open- } \\
\text { fixation }\end{array}$ & $\begin{array}{c}\mathrm{Mg}^{2+} \\
\text { inhibition } \\
10 \mathrm{mM}>1 \mathrm{mM}\end{array}$ & Procaine \\
\hline PCR & Depolarization of T-tubule & - & $\begin{array}{l}-? \\
+?\end{array}$ & + & + & $\begin{array}{l}-? \\
+?\end{array}$ \\
\hline $\begin{array}{l}\text { Clof-induced } * \\
\mathrm{Ca}^{2+} \text { release }\end{array}$ & $(>\mathrm{mM})$ & - & Inhibition & + & - & - \\
\hline CICR & $\begin{array}{l}\text { Increase in cytoplasmic } \\
\mathrm{Ca}^{2+} \text { concentration }\end{array}$ & + & + & + & + & + \\
\hline
\end{tabular}

low concentrations $(10 \mathrm{~mm}$, Figure 1$)$ but that it is still increasing at higher concentrations (Figure 2b). Under the weakly buffered conditions of the experiment shown in Figure $1, \mathrm{Ca}^{2+}$ release is enhanced by the effect of Clof on both CICR (with released $\mathrm{Ca}^{2+}$ ) and some other mechanism, while Clof cannot activate the CICR without $\mathrm{Ca}^{2+}(\mathrm{pCa}>8$ buffered with $10 \mathrm{mM}$ EGTA, Figure 2b). Therefore, Clof is more effective under weakly buffered conditions.

Whether these effects of Clof are a result of direct activation of the RyR-Ca ${ }^{2+}$-release channel or of an indirect mechanism via protein(s) binding to the RyR, for example, such as the FK-506 binding protein (Marks, 1996) or triadin (Fan et al., 1995) is an important problem to be solved.

\section{Effect on intact muscle}

Although Clof could effectively induce $\mathrm{Ca}^{2+}$ release, as caffeine can in our experimental condition (Figure 1), it has not been reported that Clof releases $\mathrm{Ca}^{2+}$ from the SR in intact skeletal muscle fibres to cause contracture as caffeine does. The action of Clof was inhibited by AMP at the $\mathrm{Ca}^{2+}$ concentration in resting living cells (around $\mathrm{pCa} 7$ ), and a similar inhibitory effect was observed with ATP $(\mathrm{pCa}>8$, unpublished observation). The rate of $\mathrm{Ca}^{2+}$ release induced by Clof in the presence of AMP was much lower than that induced by caffeine at pCa $>6$ (Figure $7 \mathrm{~b}$ ). Since ATP is present in millimolar concentrations in living cells, it is not surprising that, unlike caffeine, Clof cannot cause $\mathrm{Ca}^{2+}$ release from the $\mathrm{SR}$ of intact muscles. In addition, high concentrations of Clof may have different effects on intact cells, e.g. inhibition of $\mathrm{Cl}^{-}$channels (De Luca et al., 1992). Therefore, effects of Clof on intact cells are likely to be complex.

\section{Opening modes of Clof-induced $\mathrm{Ca}^{2+}$ release and physiological $\mathrm{Ca}^{2+}$ release in skeletal muscles}

In the Introduction, it is pointed out that CICR and PCR are two different modes of opening of the $\mathrm{RyR}-\mathrm{Ca}^{2+}$-release channel in skeletal muscles. In this study, we demonstrated that at lower $\mathrm{Ca}^{2+}$ concentrations, Clof induced an opening of RyR-Ca ${ }^{2+}$-release channels of skeletal muscle in a mode quite different from that of CICR. A question then arises as to whether the mode of Clof-induced opening of RyR channels is the same as that of PCR.

As summarized in Table 1, Clof-induced $\mathrm{Ca}^{2+}$ release had some properties similar to those of PCR. It was reported that PCR is not inhibited but enhanced in the presence of a high concentration of Fura-2 (Baylor \& Hollingworth, 1988; Hollingworth et al., 1992; Pape et al., 1993). Thus, $\mathrm{Ca}^{2+}$ is not required for PCR activation, but it only inhibits PCR. As shown in the present report, Clof-induced $\mathrm{Ca}^{2+}$ release was also activated in the absence of $\mathrm{Ca}^{2+}(\mathrm{pCa}>8)$.

In contrast to its effect on CICR, ATP does not appear to potentiate PCR. In cut fibres, when ATP was removed so that CICR activity was strongly attenuated, PCR was practically unchanged (M. Iino, personal communication). Furthermore, whereas adenine, an inhibitor of CICR in the presence of ATP, was shown to inhibit caffeine contracture of living skeletal muscle fibres, it did not inhibit the twitch of the same fibres (Ishizuka et al., 1983). This indicates that either adenine compounds do not affect PCR, or at least the effects of ATP and adenine on PCR are similar in magnitude, unlike those on CICR. Clof-induced $\mathrm{Ca}^{2+}$ release was inhibited by AMP (Figure 4), and this is at least in common with PCR in that no potentiation by adenine compounds is observed. It should be noted that Lamb and his colleagues reported that reducing the ATP concentration from 8 to $0.5 \mathrm{~mm}$ reduced PCR of the toad and the rat (Owen et al., 1996; Blazev \& Lamb, 1999). Since the range of ATP concentrations in which CICR is most affected is between 0 and $0.5 \mathrm{mM}$, the effect of ATP demonstrated by Lamb's group on PCR seems to be much weaker than that on CICR. However, clearly further investigation is necessary.

$\mathrm{Mg}^{2+}$, which exerts an inhibitory effect on CICR, appears to inhibit PCR as well, since in skinned fibres of the toad and the rat $\mathrm{T}$-tubule, depolarization is reported to cause $\mathrm{Ca}^{2+}$ release from the $\mathrm{SR}$ in low $(1 \mathrm{mM})$ but not high (10 mM) concentrations of $\mathrm{Mg}^{2+}$ (Lamb \& Stephenson, 1991; 1994). In this regard, PCR may be similar to CICR rather than to Clof-induced $\mathrm{Ca}^{2+}$ release at low $\mathrm{Ca}^{2+}$ concentrations, since the inhibition of the latter by $\mathrm{Mg}^{2+}$ is saturated at about $1 \mathrm{~mm}$ (Figure 5). However, it is common to all $\mathrm{Ca}^{2+}$-release mechanisms that qualitatively, $\mathrm{Mg}^{2+}$ inhibits $\mathrm{Ca}^{2+}$ release.

Procaine is a well-known inhibitor of CICR, and this was confirmed in the present report (Figure 6). The effect of procaine on PCR is somewhat controversial. While $10 \mathrm{~mm}$ procaine was reported not to inhibit PCR (Thorens \& Endo, 1975; Donaldson, 1985), it was also reported that procaine inhibits PCR in both amphibian and mammalian fibres (Klein et al., 1992; Garcia \& Schneider, 1995). However, even in the report that procaine inhibits PCR, the inhibitory effect of procaine on CICR appears stronger than that on PCR: while $60 \%$ of PCR remained, CICR was abolished in the 
presence of $1 \mathrm{~mm}$ procaine (Klein et al., 1992). Clof-induced $\mathrm{Ca}^{2+}$ release in the absence of $\mathrm{Ca}^{2+}$ was not inhibited by procaine (Figure 6).

Thus, Clof-induced $\mathrm{Ca}^{2+}$ release in the skinned skeletal muscle fibres has some features in common with those of PCR: it can be induced in the absence of $\mathrm{Ca}^{2+}$; they are not potentiated by adenine compounds; and inhibitory effects of procaine are weak or absent, although they are not exactly the same. In this regard, it is interesting that in the accompanying study (Ikemoto et al., 2001, accompanying

\section{References}

BAYLOR, S.M. \& HOLLINGWORTH, S. (1988). Fura-2 calcium transients in frog skeletal muscle fibres. J. Physiol., 403, $151-$ 192.

BERRIDGE, M.J. (1993). Inositol trisphosphate and calcium signaling. Nature, 361, 315-325.

BLAZEV, R. \& LAMB, G.D. (1999). Low ATP and elevated $\left[\mathrm{Mg}^{2+}\right]$ reduced depolarization-induced $\mathrm{Ca}^{2+}$ release in rat skinned skeletal muscle fibres. J. Physiol., 520, 203-215.

DE LUCA, A., TRICARICO, D., WAGNER, R., BRYANT, S.H., TORTORELLA, V. \& CONTE CAMERINO, D. (1992). Opposite effects of enantiomers of clofibric acid derivative on rat skeletal muscle chloride conductance: antagonism studies and theoretical modeling of two different receptor site interactions. J. Pharmacol. Exp. Ther., 260, $364-368$.

DONALDSON, S.K.B. (1985). Peeled mammalian skeletal muscle fibers. Possible stimulation of $\mathrm{Ca}^{2+}$ release via a transverse tubule-sarcoplasmic reticulum mechanism. J. Gen. Physiol., 86, $501-525$.

ENDO, M. (1977). Calcium release from the sarcoplasmic reticulum. Physiol. Rev., 57, $71-108$.

ENDO, M. (1985). $\mathrm{Ca}^{2+}$ release from sarcoplasmic reticulum. Curr. Top. Membr. Transp., 25, $181-230$.

ENDO, M. (1992). The calcium-induced calcium release mechanism in skeletal muscle and its modification by drugs. In Muscle Contraction. ed. Simmons, R.M. pp. 67-82. New York: Cambridge University Press.

ENDO, M. \& IINO, M. (1980). Specific perforation of muscle cell membranes with preserved SR functions by saponin treatment. J. Muscle Res. Cell Motil., 1, 89-100.

ENDO, M. \& IINO, M. (1988). Measurement of $\mathrm{Ca}^{2+}$ release in skinned fibers from skeletal muscle. Methods Enzymol., 157, $12-$ 26.

FAN, H., BRANDT, N.R. \& CASWELL, A.H. (1995). Disulfide bonds, N-glycosylation and transmembrane topology of skeletal muscle triadin. Biochemistry, 34, $14902-14908$.

GARCIA, J. \& SCHNEIDER, M.F. (1995). Suppression of calcium release by calcium or procaine in voltage clamped rat skeletal muscle fibres. J. Physiol., 485, $437-445$.

GRYNKIEWICZ, G., POENIE, M. \& TSIEN, R.Y. (1985). A new generation of $\mathrm{Ca}^{2+}$ indicators with greatly improved fluorescence properties. J. Biol. Chem., 260, 3440-3450.

HERRMANN-FRANK, A., RICHTER, M., SARKOZI, S., MOHR, U. \& LEHMANN-HORN, F. (1996). 4-Chloro-m-cresol, a potent and specific activator of the skeletal muscle ryanodine receptor. Biochim. Biophys. Acta, 1289, $31-40$.

HOLLINGWORTH, S., HARKINS, A.B., KUREBAYASHI, N., KONISHI, M. \& BAYLOR, S.M. (1992). Excitation-contraction coupling in intact frog skeletal muscle fibers injected with mmolar concentrations of fura-2. Biophys. J., 63, 224-234.

HYMEL, L., INUI, M., FLEISCHER, S. \& SCHINDLER, H. (1988). Purified ryanodine receptor of skeletal muscle sarcoplasmic reticulum forms $\mathrm{Ca}^{2+}$-activated oligomeric $\mathrm{Ca}^{2+}$ channels in planar bilayers. Proc. Natl. Acad. Sci. U.S.A., 85, 441-445.

IINO, M. (1989). Calcium-induced calcium release mechanism in guinea pig taenia caeci. J. Gen. Physiol., 94, 363-383.

IKEMOTO, T., IINO, M. \& ENDO, M. (1995). Enhancing effect of calmodulin on $\mathrm{Ca}^{2+}$-induced $\mathrm{Ca}^{2+}$ release in the sarcoplasmic reticulum of rabbit skeletal muscle fibres. J. Physiol., 487, 573582. study), another parallelism between Clof-induced $\mathrm{Ca}^{2+}$ release and PCR was shown concerning the inhibitory action of dantrolene and its newly synthesized derivatives.

We wish to thank Dr M. Iino (University of Tokyo, Tokyo, Japan) for reading the manuscript. This work was supported by a Grantin-Aid from the Ministry of Education, Science, Sports, and Culture of Japan.
IKEMOTO, T., IINO, M. \& ENDO, M. (1996). Effect of calmodulin antagonists on calmodulin-induced biphasic modulation of $\mathrm{Ca}^{2+}$-induced $\mathrm{Ca}^{2+}$ release. Br. J. Pharmacol., 118, 690-694.

IKEMOTO, T., HOSOYA, T., AOYAMA, H., KIHARA, Y., SUZUKI, M. \& ENDO, M. (2001). Effects of dantrolene and its derivatives on $\mathrm{Ca}^{2+}$ release from the sarcoplasmic reticulum of mouse skeletal muscle fibres. Br. J. Pharmacol., 134, 729-736

IMAGAWA, T., SMITH, J.S., CORONADO, R. \& CAMPBELL, K.P. (1987). Purified ryanodine receptor from skeletal muscle sarcoplasmic reticulum is the $\mathrm{Ca}^{2+}$-permeable pore of the calcium release channel. J. Biol. Chem., 262, 16636-16643.

ISHIZUKA, T., IIJIMA, T. \& ENDO, M. (1983). Effects of adenine on twitch and other contractile response of single fibers of amphibian fast skeletal muscle. Proc. Jpn. Acad., 59, 97-100.

KLEIN, M.G., SIMON, B.J. \& SCHNEIDER, M.F. (1992). Effects of procaine and caffeine on calcium release from the sarcoplasmic reticulum in frog skeletal muscle. J. Physiol., 453, 341-366.

KOBAYASHI, S., KITAZAWA, T., SOMLYO, A.V. \& SOMLYO, A.P. (1989). Cytosolic heparin inhibits muscarinic and $\alpha$-adrenergic $\mathrm{Ca}^{2+}$ release in smooth muscle. Physiological role of inositol 1,4,5-trisphosphate in pharmacomechanical coupling. J. Biol. Chem., 264, $17997-18004$.

LAI, F.A., ERICKSON, H.P., ROUSSEAU, E., LIU, Q.-Y. \& MEISSNER, G. (1988). Purification and reconstitution of the calcium release channel from skeletal muscle. Nature, 331, 315-319.

LAMB, G.D. \& STEPHENSON, D.G. (1990). Control of calcium release and the effect of ryanodine in skinned muscle fibres of the toad. J. Physiol., 423, 519-542.

LAMB, G.D. \& STEPHENSON, D.G. (1991). Effect of $\mathrm{Mg}^{2+}$ on the control of $\mathrm{Ca}^{2+}$ release in skeletal muscle fibres of the toad. J. Physiol., 434, 507-528.

LAMB, G.D. \& STEPHENSON, D.G. (1994). Effects of intracellular pH and $\left[\mathrm{Mg}^{2+}\right]$ on excitation-contraction coupling in skeletal muscle fibres of the rat. J. Physiol., 478, 331-339.

MARKS, A.R. (1996). Cellular functions of immunophilins. Physiol. Rev., 76, 631-649.

MEISSNER, G. (1984). Adenine nucleotide stimulation of $\mathrm{Ca}^{2+}$ induced $\mathrm{Ca}^{2+}$ release in sarcoplasmic reticulum. J. Biol. Chem., 259, $2365-2374$.

MEISSNER, G., DARLING, E. \& EVELETH, J. (1986). Kinetics of rapid $\mathrm{Ca}^{2+}$ release by sarcoplasmic reticulum: effects of $\mathrm{Ca}^{2+}, \mathrm{Mg}^{2+}$, and adenine nucleotides. Biochemistry, 25, 236-244.

OWEN, V.J., LAMB, G.D. \& STEPHENSON, D.G. (1996). Effect of low [ATP] on depolarization-induced $\mathrm{Ca}^{2+}$ release in skeletal muscle fibres of the toad. J. Physiol., 493, 309-315.

OYAMADA, H., IINO, M. \& ENDO, M. (1993). Effects of ryanodine on the properties of $\mathrm{Ca}^{2+}$ release from sarcoplasmic reticulum in skinned skeletal muscle fibres of the frog. J. Physiol., 470, $335-$ 348 .

PAPE, P.C., JONG, D.S., CHANDLER, W.K. \& BAYLOR, S.M. (1993). Effect of fura-2 on action potential-stimulated calcium release in cut twitch fibers from frog muscle. J. Gen. Physiol., 102, $295-$ 332.

RAJU, B., MURPHY, E., LEVY, L.A., HALL, R.D. \& LONDON, R.E. (1989). A fluorescent indicator for measuring cytosolic free magnesium. Am. J. Physiol., 256, C540-C548.

RÍOS, E. \& PIZARRO, G. (1991). Voltage sensor of excitationcontraction coupling in skeletal muscle. Physiol. Rev., 71, 849908 . 
ROUSSEAU, E., LADINE, J., LIU, Q.Y. \& MEISSNER, G. (1988). Activation of the $\mathrm{Ca}^{2+}$ release channel of skeletal muscle sarcoplasmic reticulum by caffeine and related compounds. Arch. Biochem. Biophys., 267, 75-86.

SCHNEIDER, M.F. (1994). Control of calcium release in functioning skeletal muscle fibers. Anпи. Rev. Physiol., 56, 463-484.

SCHNEIDER, M.F. \& CHANDLER, W.K. (1973). Voltage dependent charge movement of skeletal muscle: a possible step in excitationcontraction coupling. Nature, 242, 244-246.

SMITH, J.S., CORONADO, R. \& MEISSNER, G. (1986). Single channel measurements of the calcium release channel from skeletal muscle sarcoplasmic reticulum: activation by $\mathrm{Ca}^{2+}$ and ATP and modulation by $\mathrm{Mg}^{2+}$. J. Gen. Physiol., 88, 573-588.

SMITH, J.S., IMAGAWA, T., MA, J., FILL, M., CAMPBELL, K.P. \& CORONADO, R. (1988). Purified ryanodine receptor from rabbit skeletal muscle is the calcium-release channel of sarcoplasmic reticulum. J. Gen. Physiol., 92, 1-26.

SUKHAREVA, M., MORRISSETTE, J. \& CORONADO, R. (1994). Mechanism of chloride-dependent release of $\mathrm{Ca}^{2+}$ in the sarcoplasmic reticulum of rabbit skeletal muscle. Biophys. J., 67, $751-765$.
SUZUKI, A., MATSUNAGA, K., MIMAKI, Y., SASHIDA, Y. \& OHIZUMI, Y. (1999). Properties of amentoflavone, a potent caffeine-like $\mathrm{Ca}^{2+}$ releaser in skeletal muscle sarcoplasmic reticulum. Eur. J. Pharmacol., 372, 97-102.

TAKESHIMA, H., IINO, M., TAKEKURA, H., NISHI, M., KUNO, J., MINOWA, O., TAKANO, H. \& NODA, T. (1994). Excitationcontraction uncoupling and muscular degeneration in mice lacking functional skeletal muscle ryanodine receptor gene. Nature, 369, $556-559$.

THORENS, S. \& ENDO, M. (1975). Calcium-induced calcium release and "depolarization"-induced calcium release: Their physiological significance. Proc. Jpn. Acad., 51, $473-478$.

XU, L., TRIPATHY, A., PASEK, D.A. \& MEISSNER, G. (1998). Potential for pharmacology of ryanodine receptor/calcium release channels. Anal. N.Y. Acad. Sci., 853, 130-148.

ZORZATO, F., SCUTARI, E., TEGAZZIN, V., CLEMENTI, E. \& TREVES, S. (1993). Chlorocresol: an activator of ryanodine receptor-mediated $\mathrm{Ca}^{2+}$ release. Mol. Pharmacol., 44, $1192-$ 1201.

(Received March 14,2001 Revised July 24, 2001 Accepted July 30, 2001 